DOI: 10.2478 /ausfm-2014-0032

\title{
Quasi-Bodies and Kafka's Castle in Sion Sono's Crime Noir Guilty of Romance (2011)
}

\author{
Chia-wen Kuo (Veronique Kwak) \\ National Chengchi University (Taiwan) \\ E-mail: gloomydaisy@hotmail.com
}

\begin{abstract}
Sion Sono's Guilty of Romance (Koi no tsumi, 2011) was adapted from an actual crime in Tokyo's love hotel: an educated woman (a prostitute at night) was found decapitated and her limbs were re-assembled with a sex-doll. Sono renders this through his cinematic narrative blurring the distinction between true crime and fictional sin like Rancière's idea that everything is a narrative dissipating the opposition between "fact and fiction," and "quasi-body" becomes a product of human literarity while an imaginary collective body is formed to fill the fracture in-between. In Sono's story, the victim is a literature professor tormented by an incestuous desire for her father, whose favorite book is Kafka's Castle. Thus she compares the love-hotel district where she turns loose at night as a castle of lusts. Here the narrative becomes a collective body that puppeteers human "quasi-bodies" in a Kafkaesque spatio-temporal aporia, and time's spatialized horizontally with the germs of desire spread like a contagion on a Deleuzian "plane of immanence."
\end{abstract}

Keywords: Sion Sono: Guilty of Romance (2011), Franz Kafka: Castle, "quasi-body," crime noir.

\section{Introduction}

Sono's Guilty of Romance revolves around two females: a housewife whose husband is a famous author of pot-boiler romance novels and a literature professor filled with an incestuous desire and longing for her absent father. Their excessive libidinal energies are intermingled with their obsession with words, and the professor convinces the housewife to explore along with her the unfathomable depths of her lust by methodically seducing her into a secret nocturnal life as street prostitute. The film is thus often seen as a Japanese version of Belle de Jour (1967), in which a straight-laced middle-class housewife plunges herself into a series of debaucheries in quest of her true self, a life of passion which mocks the hypocrisy 
of French bourgeois society. In Sono's film the housewife comes to acknowledge that her body is given a new meaning as each act of sexual degeneracy leaves a mark upon her. "Welcome to love's inferno" - a variation on Dante's "Abandon all hope ye who enter here" - becomes a slogan in the movie. At the height of the two woman's sensual exhilaration, their flesh and by extension that of all such women becomes that of a "quasi-body" lacking "a legitimate father" - where now we will think of the "collective body" of patriarchal rationality since man here becomes both the object and catalyst of female "transgressions."

Finally the professor's husbandless mother, hating and also jealous of her daughter, convinces the housewife to kill the professor. The mother then performs the duty of "public sanitization" - here we are reminded of Malmgren's analysis (see section III. Crime Narratives, Rancière's Quasi-Bodies, and Deleuzian Cinema) - by dismembering her body, which she considers diseased, contagious; she replaces the polluted genitals with a sex-doll and isolates the former from any possible public exposure so the "disease" cannot spread. Then the mother commits suicide when the investigators arrive. In actuality (not the movie), the murderer is, like Jack the Ripper, never caught so the status quo is never restored. In Sono's fiction, those fictional female characters, who choose to unbridle their wild libido and expand the disorder within this society, are punished instead. Within the film, based as it is on an actual case, a true case history, the logics of facts and fiction are entwined.

\section{Oedipal and Anti-Oedipal Femme Fatales}

The title of the film, Guilty of Romance, leaves us with a sense of ambiguity, as we cannot help but wonder whether it is about psychology or religion, romance or sex. A guiding theme of this movie is that of one woman's desperate love for her father and another woman's smoldering desire for her seemingly chaste husband. As Jean-Luc Nancy says in Shattered Love, love here belongs to the domain of "the impossible," which means that it could make us aware of our own finitude, could be self-destructive. As Nietzsche’s Zarathustra says, "Great loves do not want love - they want more" (Nancy 1991, 93-99). That is, love is always insatiable, a sort of void.

On the contrary, desire is the opposite of love, according to Nancy; it aims to be fulfilled precisely through "lacking its object" and "extending toward its end" $(1991,98)$. The professor tells the housewife that sex can never be experienced in vain: if you're having sex with someone whom you don't love, you must charge him money as a matter of principle. The women offer their flesh in exchange 
of money as if performing an ancient ritual: love is in the realm of gift-giving while desire is merely a form of exchange. But love also contradicts the notion of gift-giving since wives, children, and perhaps husbands are held as property; it thus "frustrates the simple opposition between economy and non-economy" (property and gift). However, love terminates this opposition "without sublating or surmounting it" (96). Unable to obtain a complete and perfect love, women suffer from a severe feeling of self-negation, precipitated into love's inferno where bits of identities are eclipsed until they totally disappear because love can never "withhold its identity behind its shatters" (Nancy 1991, 99), and their chosen way to realize this impossibility of love's infinity is through death and decay.

Žižek dissects the idea of the Femme Fatale in Two Ways to Avoid the Real of Desire. In his Lacanian interpretation of Film Noir, the Femme Fatale is the woman who subjectifies her fate through brazenly "assuming the death drive." Žižek defines the position of the Femme Fatale as that of a "non-existence assumed through her hysterical breakdown." That means the woman becomes a menace to man by simply materializing her inherent masochistic desire for self-ruin; consequently she is no longer the object but the subject, even the pure subject who is totally able to govern her own fate. Žižek also supposes that the man who identifies with this woman is suicidal as he self-willingly submits himself to his "symptom." (Here we get the Lacanian notion that "Woman is the symptom of man") (Žižek 1998, 65-66).

But the Freudian and Lacanian psychoanalysis of cinema does have its limitations inasmuch as it fails to transcend identity politics. For Deleuze and Guattari each of us is a "multiplicity," so in the first place there is no Daddy Mommy Me triangle, itself a construction of the desiring-machine of capitalism. In the Freudian-Lacanian view, which Žižek to a degree adopts, the protagonist is forced to undergo the process of "Oedipalization" because he/she is unable to break free of the family romance; "the desiring-production is displaced, 'travestied' into an 'Oedipal sub-aggregate"' (Anti-Oedipus). Here the schizo is unjustly "neurotized" into an impotent state, and a "neurotized" schizoid is restrained from exercising the power of affect. Therefore, Deleuze sees "schizophrenia as process" in the "affective dimension" (Pisters 2008, 105), and the neo-FemmeFatale as a woman who attempts to break loose from the confinements of family romance, is also a woman who drives her desiring machine in full throttle.

Guilty of Romance shall be an affective dimension that emulates a schizophrenic automaton sufficed by multiple time-images, and the women in it are all triggered by "the relations to the affects" (Pisters 2008, 112). As for how the "guilty of 
romance" women surpass the limits of "oedipalization," they metamorphose themselves into "the body without organs" as the professor turns her flesh into obsolescence: she yields her own body to the sexual dissipations to start her journey in "love's inferno," and at last she becomes "the body without organs" in the highlight of her orgiastic sensations in which she is emotionally devastated with self-loathing, she perishes into a decapitated corpse re-assembled with a plastic sex-doll (body without an image) (MacCormack 2001, 133). Tragically, self-obliteration becomes the only means to sabotage the pattern of her Electra complex as she abolishes the "power of speech" by re-incarnating herself into the Rancièrean quasi-body within the castle of lust.

\section{Crime Narratives, Rancière's Quasi-Bodie, and Deleuzian Cinema}

Carl Malmgren claims in Anatomy of Murder that criminal investigation in detective fictions serves to "formalize" or reduce the conflict between the rational and the irrational since the detective hero bravely "exorcises" the irrational, returning us to some semblance of a rational order (Malmgren 2001, 176). Similarly, Carla Freccero speaks of the "disavowal of institutionalized violence" in American serial killer fiction, since the acts of an individual, isolated serial killer contrast sharply with the concept of a "violence-situated [...] culture." Thus this perverse and abnormal violence is grounded in an individual's "psychosexual dysfunction" rather than in a larger societal malfunction, and the ultimate solution is always to eradicate the killer to restore your faith in the social norm, that is, in a projected illusion of status quo (Malmgren 2001, 177). However, in Tokyo's lovehotel murder the actual killer is, like Jack the Ripper, still at loose and so the force of rationality fails to fully exercise its proper function; Guilty of Romance reminds the Japanese readers of the irrational forces that still lurk within Japanese society.

In fact, the process by which police detectives (or private investigators, private eyes, as in The Maltese Falcon [John Huston, 1941] and other classic American versions of "film noir") attempt to solve murder cases is similar to the scientist's process of trying to prove a theory through the investigation of experimental hypotheses. And the hypotheses of crime investigators are not unlike scientific theories themselves, which try to explain the outcome of a series of events in time - "Drop something and then another thing and each case the object will fall," though of course we get more elaborate formulations such as "If X had been the cause of Y (If John Jones had killed her) then we would have expected outcome Z 
(He would have already disappeared), but this is not the case," etc. History itself as well as scientific theory is of course a narrative, a story, an account of a series of events in time, and in any sort of narrative or "case history" we can freely move back and forth in time (into the past/future). History, scientific theory, the case history of a crime and the plot of a novel, drama, epic poem, or film all mix true and false, fact and fiction (myth, legend, hyperbole).

The above, perhaps too-obvious point is already presupposed by Rancière, who notes in The Politics of Aesthetics that the lack of a distinction between "the logic of facts" and "the logic of fictions" could lead to an "inter-dependentness" and a "a new mode of rationality, one that characterizes the science of history" (Rancière 2004, 36). Thus, by blurring the boundary between fiction and history, one could develop a new form of narrative conceived as a rational discourse of and on human society. ${ }^{1}$ The manipulation of this narrative, Rancière says, would be a form of construction of "the real" since "the real must be fictionalized in order to be thought" (38). In the case of Sion Sono's crime noir, Guilty of Romance, Sono utilizes the factual record of the decapitation of a woman in Tokyo's love-hotel district to fabricate a gory urban tale. In fact the killer, who left the beheaded victim with her head and limbs displaced like those of a plastic sex-doll, was never found. We might say that Sono takes advantage of this sensational true story to confuse viewers' normal ability to distinguish the rational and irrational. Thinking of Malmgren's analysis, the question might even arise here as to which is more "real," the notion of a fundamentally rational society or that of a fundamentally irrational one.

Young children, Aristotle points out in the Poetics, love stories because mythos (narrative) "is life," that is, our life itself takes the form of a narrative, a series of events in time. If man is for Aristotle a political animal due to his innate narrativity, Rancière says that our "literarity" is expressed through many forms of locution, each of which becomes a "quasi-body" or "block of speech" (Deleuze's term in A Thousand Plateaus) that "circulates without a legitimate father" so that we ourselves really are or become a "heterotopia" (Foucault), a homogenizing "collective body" whose essence is "fractured and disincorporated" (Rancière 2004, 39). Here again we have the influence of Deleuze, in this case his "body without organs," which among other things can imply a purely "virtual” body.

In Deleuze's theory of cinema we have the power of the virtual, speech, and affect. According to Patricia Pisters (2008), "the virtual and the actual start

1 "The notion of 'narrative' locks us into positions between the real and artifice ... a matter of claiming that everything is fiction” (Rancière 2004, 38). 
chasing each other to the point where they become indistinguishable," at which point we get the manifestation of "a mental reality:" this consists of time-images rendered through the power of the virtual as the symptom of "a schizophrenic delirium," where the latter is not "actual" but it is "very real." In other words, these quasi-bodies lacking a collective body are neutralizing each other in the virtual-actual or fiction-history aporia, while spatiality is temporalized as a series of time-images derived from the protagonist's desire. In the first half of the $20^{\text {th }}$ century, cinema was "a machine of the visible" which represented "an illusion of reality" in order to restore the audience's perception of the material world. ${ }^{2}$ But in Deleuzian schizoanalytic film theory cinema has now become "a machine of the invisible" that intercepts the time-images within our mind/brain to project a "reality of illusion" rather than to introject movement-images into our mind. Meanwhile, "the spectator" is turned into "a disembodied eye" (a surrogate organ of touch) - a disjointed quasi-body interwoven within the process of complicit voyeurism/exhibitionism (Pisters 2008, 112).

Thus in Guilty of Romance, one woman lures another woman to be a voyeur, watching from a distance the first woman's series of sexual encounters, and then forces her to join as a participant at wild orgies (Pisters 2008, 113). One pornographic scene after another is accompanied by Mahler's Symphony N. 5, creating a decadent and delirious mise-en-scène. Through this "intersubjective spectatorship" (Linda Williams), the story is told without linear narrations but in series of flowing images "ambiguously enfolded in each other," thus dissolving human desire into a fluid flux while the differentiation between the virtual and the actual (history and fiction) is dismissed. Deleuze indeed says we should not ask "Does cinema give us an illusion of the world?" but rather "How does cinema restore our belief in the world?" (Pisters 2008, 114). Guilty of Romance is Sion Sono's cinematic attempt to recuperate our faith in the world.

\section{Film Noir, Malaise, and Kafka's Castle}

In A Panorama of American Film Noir: 1941-1953 we learn that film noir creates a "state of tension created in the spectators by the disappearance of their psychological bearings" (Borde and Chaumeton 2002, 13). That is, film noir exposes the inherent reality of irreconcilable human conflict; it gives us

2 In his essay Art in the Age of Mechanical Reproduction Walter Benjamin argues that cinema could be an effective state-apparatus of the fascists or communists of the 1930's, if they exploited the mesmerizing power of the cinematic "aura." 
"the moral ambivalence, criminal violence, and contradictory complexity of [...] situations and motives" in order to conjure up a collective consensus of "anguish or insecurity" (Giltre 2009, 21). The power of affect in Noir (literally "Black" in French) is that of "a specific sense of malaise" which envelopes everything, and may perhaps be best grounded in a painterly and cinematic technique, a "chiaroscuro space" [Figs. 1-2] $]^{3}$ where light and shadow (clear/obscure, light/ dark, light/shadow) are sharply contrasted. This suggests various binarisms including that of good/evil and life/death, and contributes to the spectators' sense of tension, confusion, "loss of bearings."

In Noir, the demarcation between fiction and history is also erased due to the grim verisimilitude within the hard-boiled detective-narrative, reminding us that both are forms of narrative and perhaps suggesting something like a Nietzschean "eternal recurrence of the same" (in any-space-whatever) (Shaw 2008, 158). A flattened-out temporality such as Nietzsche sometimes suggests as one interpretation of the eternal return also can fit several of Kafka's works and major themes. That is, in Kafka we are often trapped in a sort of "progress of infinite delay" of infinitely-delayed journey, where the journey itself is often across a flat surface (The Imperial Messenger in The Great Wall of China), even where we might have expected it to be vertical. ${ }^{4}$

Indeed, "Kafkaesque" is phrase frequently applied to Noir, given the latter's constant sense of an impasse and of the dark side of human nature. In Guilty of Romance, the favorite book of the professor-protagonist's dead father was (is) Kafka's later novel The Castle. ${ }^{5}$ In the film the professor delineates the clandestine side of her double-life via the enigmatic contours of The Castle. It becomes for her a spatial allegory of Tokyo's love-hotel district, above all because the novel and castle seem(s) to be a labyrinth with no exit, and to have again a sense of time so that flattened-out time so that there is in effect also "no beginning" and "no ending."

3 In Orson Wells's noir classic The Lady from Shanghai (1948) starring Rita Hayworth, the adulterers (the third party, the femme fatale, and her impotent husband) enter into "The Magic Mirror Maze" where they shoot each other into death when the husband utters "of course, killing you is killing myself. It's the same thing. But you know, I'm pretty tired of both of us!" The mirror-maze could be another metaphor of Kafkaesque castle where entraps the sinners in a snare of desires consummated by death, visible, intangible, and somehow concretized through chiaroscuro, in opposition to that in Guilty of Romance (2011). It could also be another form of Gaia which the men here aim to destroy in order to cut loose from the Femme Fatale.

4 "Before the Law" in The Trial, where the Law lies not "above" as we might have expected but in the innermost chamber of a labyrinth. We also get the horizontal labyrinthine structure in The Imperial Messenger.

5 In the wider domain of contemporary Japanese narrative, one of Murakami's bestknown novels is Kafka on the Shore. 
Herman Pongs (1960) notes that Kafka is the writer of the labyrinth which he sees as an effective image of a world out of joint. The design of the labyrinth - a place from which its own designer (Daedalus) could not escape until he resorted to the third dimension, the vertical, and flew upward - also suggests the paradoxical juxtaposition between light/dark, good/evil, life/death. Kafka's labyrinthine castle becomes what Pong calls "a shrunken form," and what Gustav Rene Hocke defines as "a metaphor unifying the calculable and the incalculable elements of the universe." Heinrich Politzer says that Kafka's The Castle is a clear embodiment of the labyrinth as cosmological dichotomy (Politzer 1962, 231), and that the telephone wire within the story demonstrates "the Castle's paradox in time," while the castle's "vibrating infinity" is also "a paradox in space" (Politzer 1962, 248). In Guilty of Romance, the housewife receives cell-phone calls from the seediest corners of the city, and she is compelled to leave her leisure life of plentitude and descend into a disoriented and disorienting space where time bears no consequence, an oblivion like that of "ever more deceiving spirals" as if "eternity prevails" (Politzer 1962, 252).

In the love-hotels of Tokyo, the interior design of the rooms includes mirrors which enable the couples to gaze upon themselves during their private activities. The mirrors can fulfill the obsessive narcissistic desires of adulterers: to watch yourself during sex means you are in effect making love to the reflected image(s) in the mirror(s) instead of to your partner, who is in a way "absent" from the lovescene. The mirrors of the love-hotels suggest the nothingness of "the castle" whose "inner chamber not only shelters nothingness, but, combined with it in absolute ambiguity, the promise of total existence" (Politzer 1962, 263), as if it were an allencompassing Gaia (Earth-Mother as in Hesiod's Theogony) exercising its potency to punish the female sinners within "its majestic impassivity" (Politzer 1962, 267). Still, like the male protagonist of The Castle, the "guilty of romance" ladies are kept in a state of "incessant longing for a certainty." This brings us back to the nature of film noir and more generally to the nature of cinema in general. Spencer Shaw states that cinema is "a singular space" which ceases to be "determined" for it has become an "any-space-whatever" consisting of numerous "linkages" as well as a series of "virtual conjunctions" (Shaw 2008, 157).

In the case of Guilty of Romance, it pays homage to Noir by de-constructing a page of murder history into a Deleuzian "plane of immanence" since the old aesthetic dimension of chiaroscuro is internalized as a mental picture (brain is the screen) projected through "a machine of the invisible." Here, Western binarism as well as the phallocentric world of hard-boiled criminality is disintegrated by the saturation of colors in which "femininity" and the "the exotic other" prevail. 
The standardized noir is "internal anxieties bleed out, disrupting realism in favor of expressionist stylization" (Giltre 2009, 12), and the intervention of colors in neo-noir ${ }^{6}$ is "a shattering of unity" according to Julia Kristeva, because colours "interrupt the process of self-formation" and the result shall be that colors manage to "de-differentiate the self and de-form the world" into a series of accelerated derangements, in which each noir individual fail to find an exit as he/she is "trapped in the patterns of behaviors beyond their control" (Giltre 2009, 21).

Furthermore, Jacques Rancière mentions in The Aesthetic Unconscious that the position of art in Freudian unconscious is situated between "knowing and not-knowing, sense and non-sense, logos and pathos, the real and the fantastic," (Rancière 2010, 53) but the aesthetic unconscious "radicalizes" one's identity into "contraries" (Baumgarten's "confused clarity") (2010, 24). The aesthetic unconscious aims to demolish this binarism in order to reach toward a "nihilist entropy" (Schopenhauerian will of nothingness) $(2010,88)$ in its confrontation "with the power of the Other" $(2010,85)$. Thus neo-noir attests to this Rancièrean embodiment of aesthetic unconscious through its saturation of contrastive colors, and there's no Oedipal denouement but an aesthetic sublime in which the Dionysian abandon triumphs.

\section{Intertextuality: Words and Images}

During the movie, the poetry of Tyuichi Tamura is introduced in a scene where the doomed professor is lecturing on Tamura's On My Way Home in her university:

I should never have learned words

How much better off I'd be

If I lived in a world

Where meanings didn't matter

The world with no words

If the beautiful words take revenge against you

It's none of my concern

If quiet meanings make you bleed

It also is none of my concern

6 Kathrina Giltre expounds, the use of colors in neo-noir could be just to "accentuate chiaroscuro lighting by using contrasting colors" $(2009,21)$. But in the case of Guilty of Romance, this "accentuation of chiaroscuro" is manifest in the poster as well as the criminal scene where the corpse is found through the use of crimson red (blood) and the ominous gleam of dark purple in the background [Fig. 3]. 
The tears in your gentle eyes

The pain that drips from your silent tongue -

I'd simply gaze at them and walk away

If our world had no words

I should never have learned words

Simply because I know Japanese and bits of a foreign tongue

I stand still inside your tears

I come back alone into your blood (Tamura).

While the professor is reciting this poem in front of her class, the housewife steps into the classroom. We cannot foresee the ensuing tragedy when we see the two women's faces glowing with a sense of excitement, a secretly shared intimacy. In the film's last frame the camera stays on the housewife's bruised face, a stream of blood flowing from one nostril [Fig. 2] while her eyes exude a strange delight in the reminiscence of her friend.

Thus the poem, which might have been "spoken" by either woman, makes us think about the two women's relationship and how it ended. It also summons the viewers' memory of these two women's first rendezvous [Figs. 5-7] in which words also seemed to cease to matter. The women along with those words they aspire to do away with now appear, in effect, as those "quasi-bodies" or "blocks of speech" that they have become within the collective body of Tokyo's "love-hotel."

Structurally Sono chooses to interpret the story of Guilty of Romance posthumously while he embeds many intervals to shatter off "images in a chain" in a Proustian manner, which could be "a force between the determining and the determined, within time" (Shaw 2008, 163). Events are dissolved into the remnant fragments of memories as we witness one random picture of a missing female on the wall of police bureau [Fig. 8] then we jump into her story narrated through "image-in-movement." By Laura Marks's appropriation of "transitional object" from D W Winnicott's object-relation theory, the picture of the missing woman is a transitional object as well as a "fossil" to serve a "radioactive" purpose to invite the audience into "decoding the past" of the actual event, but here transitional object becomes a "fetish" since "cinematic images obscure" the truth of the actual event (whose power is liquefied) by "connecting it to memory" and then fossils are now turned to "recollection-images" (Marks 2000, 124).

All of a sudden, the audience is forced to return to the crime scene where the horribly severed body on the morgue table turns the mellow memory into a grotesque ruin (Fundamental allegory of Noir). Everything "spreads out and 
transmits" in a fluid mode without solid fixation just like the displaced bodyparts of the victim - a "diffused" becoming, a body without organs within the "gaseous" plane of immanence (Shaw 2008, 163).

Merleau-Ponty notes that human relationship with the world is mimetic while Deleuze claims in his Cinema 2 that cinema gives the spectators "the genesis of an unknown body" (Marks 2000, 147). Here, self and the world are "enfolded" in the film-viewing experience as cinema spectatorship becomes "the exchange between two bodies" - "the self-in-becoming" and "its embodied intercessor," and this mimetic bond between the spectator and cinema seems to simulate the Lacanian mirror-phase (Marks 2000, 151). But unlike the Lacanian mirror-phase, the distance between the beheld and the beholder is cancelled to reach an extent beyond voyeurism. By Laura Marks's definitions, “optical composition” annuls the "representational power of the image" through the lack between the gazer/ gazed so the gazer could obtain an assured sense of self through constructing him/ herself as "an all-perceiving subject." This lack-in-between is where voyeurism thrives. On the other hand, in the case of "haptic composition," the lack-inbetween is nullified to transcend the optical voyeurism, and it is more concerned with the body as well as its "tactile materiality." In other words, haptic visuality sheds off the shackles between the self/other to attain a state where "the eyes themselves functions like organs of touch" (Marks 2000, 162). The stereotypical understanding of haptic by Riegl would be the visual provocation through "the blurring of chiaroscuro" - a disturbance to the abstractive function toward the “all-perceiving subject.” But Marks has expanded this idea into another domain where the discussion of subject is made absent while the body reigns.

Let's associate Marks's categorization of optical/haptic composition in the transformations of Noir. Classic noir is constructed on the wrestle over the contrastive opposition between light and shadow [Fig. 1] through optical composition, where the language of noir becomes "standardized" and heavily reliant upon the narratives; the future of neo-noir exists in the place of Deleuzian time-image, where the viewer is "contemplating" the image itself (rather than get absorbed into the narrative) through haptic composition which focuses upon affects. That is, the language of classic noir is more about "narrative identification" while that of neo-noir is concerned more with "bodily identification" (Marks 2000, 170-71), just like Tyuichi Tamura's On My Way Home, in which words/narratives cease to matter while the bodily objects like tears and blood are channeling the might of affects in a more mimetic way that requires a more immediate "haptic composition" from the beholder. 


\section{Conclusion: Cinematic Body as the Prefigured Maternal Space}

Throughout the film, man occupies in the position of the lack as well as the symptom of woman. One female intrigues another to voyeur her acts of fornications, and the voyeur is snatched into scene for actual participation as the spectator's "erogenous body is created through a pure dispersed and anarchic multiplicity." Hence, the discourse of spectatorship is also liquefied while the erogenous body (of the spectator) turns to be "a territory of becoming through relations of desire" (MacCormack 2008, 139). The females here engage themselves in a game of voyeur devoid of man, and they surrogately make love (a lovemaking without actual sex) through their voyeuristic gestures of each other until they disintegrate each other into "singularities."

Or, this seemingly voyeuristic game between the two females here could be a haptic erasure between self/other: in the beginning, the protagonist (the housewife) is cajoled in the underground pornography as the gravure girl; she is the beheld to be preyed with the eyes of the beholders. Later in her encounter with the professor who is a street-prostitute at night, she is the gazer who rejoices in others' affairs with detachment until she is forcefully snatched to join the scene as the distance between the beheld and the beholder no longer exists. Through this bodily involvement, she is no longer just a voyeur tickled in the delight of optical visuality but a participant overwhelmed in the thrill of haptic visuality till she totally loses herself in the haunted abyss of "death, degeneration and destruction" as one woman is literally transmuted into "body without organs" while the other takes over her place to continue the street-prostitutions, just like a ceremony performed in the manner of the Nietzschean "eternal recurrence of the same" in the inferno of love - a Kafkaesque spatio-temporal aporia.

Laura Marks elucidates, it is "the self-eclipsing desire" that "propels haptic visuality" as the eroticism in female spectatorship resembles more of the bond between mother and infant rather than "phallic economy" $(2000,188)$, and it borders upon the pre-lingual stage where language is not needed (Julia Kristeva's Chora $^{7}$ ). In the end, even the sexes become joyless while love is turned to the eruption of their shattered multiplicities. The last bit of remaining

7 Anne-Marie Smith explains that Kristeva brings forth "a third dimension" where "the sensation, vocalics and images" prevail while "the semiotics” within ,the Lacanian imaginary and symbolic" are expelled, and the state of "non-differentiation" is attained by the absence of father, just like a dark room that resembles a "prefigured maternal space" (Smith 1998, 60). 
love becomes a fetish to evoke the recollection-image of the professor's reciting of On My Way Home:

I should never have learned words

Simply because I know Japanese and bits of a foreign tongue

I stand still inside your tears

I come back alone into your blood (Tamura).

The woman's eyes are blazed with an ecstatic joy over the dismantled, fetishised "body" of her late friend [Figs. 4-8].

\section{References}

Borde, Raymond and Etienne Chaumeton. 2002. Toward a Definition of Film Noir. In A Panorama of American Film Noir: 1941-1953. San Francisco: City Light Books.

Buchanan, Ian and Patricia MacCormack. 2008. Deleuze and the Schizoanalysis of Cinema. New York: Continuum.

Glitre, Kathrina. 2009. Under the Neon Rainbow: Colour and Neo-Noir. In NeoNoir, eds. Mark Bould, Kathrina Glitre, and Greg Tuck. London \& New York: Wallflower Press.

MacCormack, Patricia. 2008. An Ethics of Spectatorship: Love, Death and Cinema. In Deleuze and the Schizoanalysis of Cinema, ed. Ian Buchanan. New York: Continuum.

Malmgren, Carl D. 2001. The Police Procedural and Serial Killer Fiction. In Anatomy of Murder. Ohio: Bowling Green State University Popular Press.

Marks, Laura U. 2000. The Skin of the Film: Intercultural Cinema, Embodiment, and the Senses. Durham and London: Duke University Press.

Nancy, Jean-Luc. 1991. Shattered Love. In The Inoperative Community. Minnesota: the Regents of the University of Minnesota.

Pisters, Patricia. 2008. Delirium Cinema or Machines of the Invisible. In Deleuze and the Schizoanalysis of Cinema ed. Ian Buchanan. New York: Continuum.

Politzer, Heinrich. 1962. The Bitter Herb: The Castle. In Franz Kafka: Parable and Paradox. New York: Cornell University Press.

Pongs, Hermann. 1960. Franz Kafka: Dichter des Labyrinths [Franz Kafka: Poet of the Labyrinths]. Heidelberg: Wolfgang Rothe Verlag.

Powell, Anna. 2008. Off Your Face: Schizoanalysis, Faciality and Film.In Deleuze and the Schizoanalysis of Cinema ed. Ian Buchanan. New York: Continuum. 
Rancière, Jacques. 2004. Is History a Form of Fiction? In The Politics of Aesthetics. Britain: Gabriel Rockhill.

Rancière, Jacques. 2010. The Aesthetic Unconscious. Cambridge: Polity Press.

Sono, Sino. 2011. Guilty of Romance. Japan: Eureka Entertainment.

Shaw, Spencer. 2008. Film Consciousness: From Phenomenology to Deleuze. North Carolina: Shutterstock.

Smith, Anne-Marie. 1998. Julia Kristeva: Speaking the Unconscious. London: Pluto Press.

Tamura, Ryuichi. 2007. On My Way Home. In Poetry International, transl. Takako Lento. http://www.poetryinternationalweb.net/pi/site/poem/item/9470 Last accessed at 18. 04. 2014.

Žižek, Slavoj. 1998. Two Ways to Avoid the Real of Desire. In Looking Awry: An Introduction to Jacques Lacan through Popular Culture. Cambridge: The MIT Press. 


\section{List of Figures}

Figures 1-2. "Chiaroscuro space" in Orson Welles's cinema (The Lady from Shanghai, 1948).
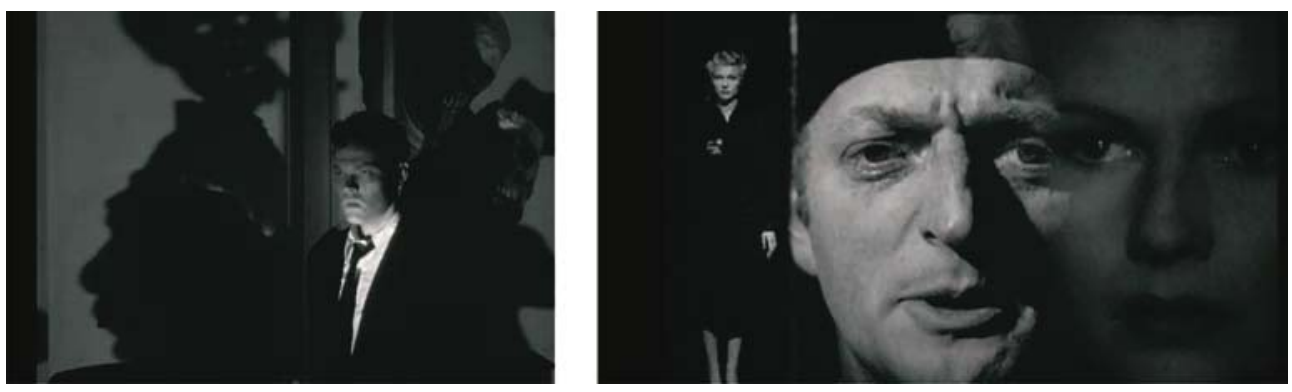

Figures 3-8. Sion Sono: Guilty of Romance (2011).
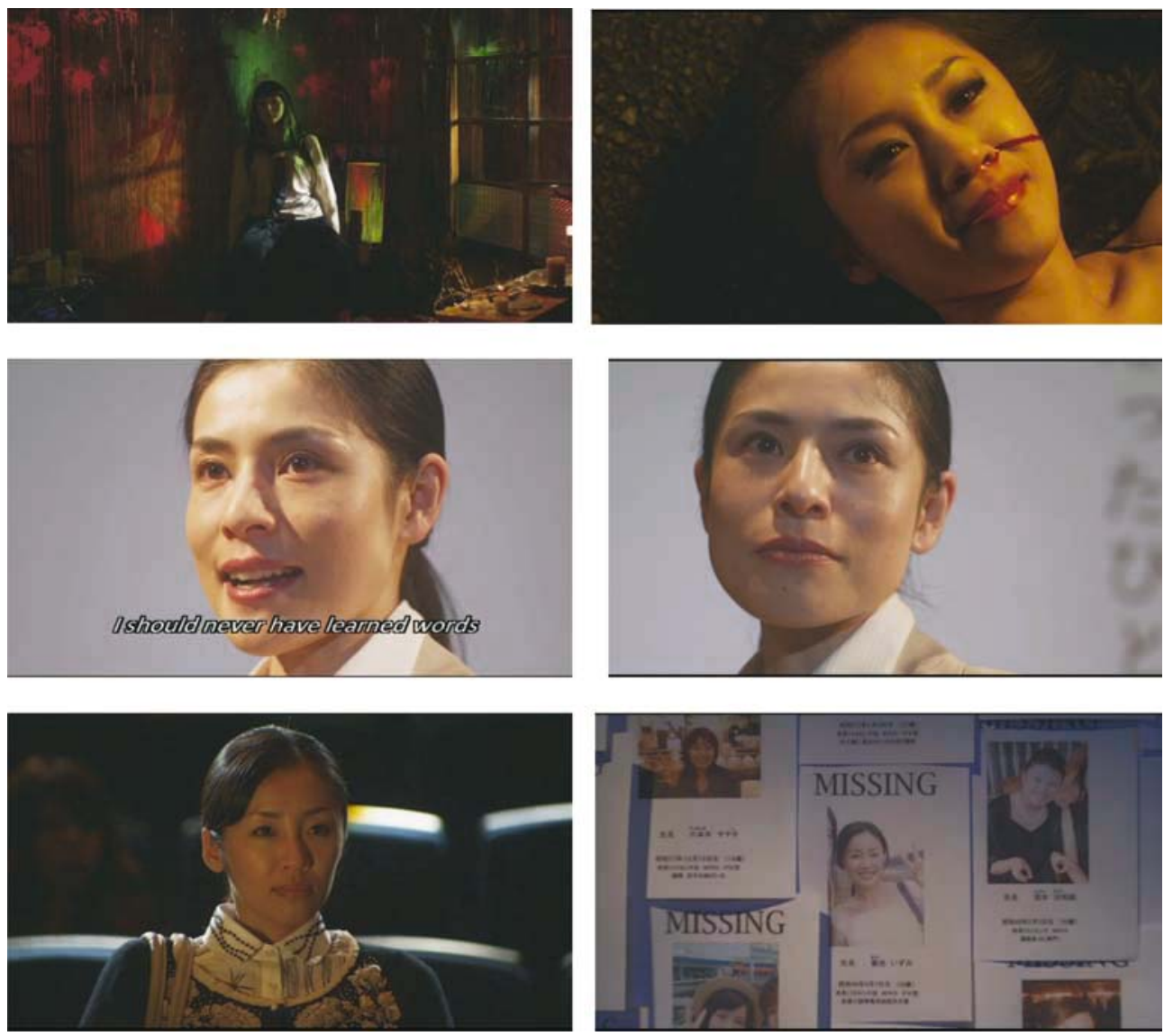